\title{
ANALYSIS OF MARKET STRUCTURE, CONDUCT AND PERFORMANCE OF COPRA IN PARIGI - MOUTONG REGENCY
}

\author{
Hendra Kurniawan $^{1 *}$, Ratya Anindita ${ }^{2}$, Silvana Maulidah $^{2}$ \\ ${ }^{1}$ Post Graduate Program, Faculty of Agriculture, Brawijaya University, Indonesia \\ ${ }^{2}$ Faculty of Agriculture, Brawijaya University, Indonesia \\ ${ }^{*}$ corresponding author: endap2214082@gmail.com
}

\begin{abstract}
This study aims to find out and investigate how copra farmers receive in Parigi - Moutong Regency. In this study the data used is primary data and secondary data, primary data is taken using questionnaire list. This research uses IHH and CR4 analysis approach, with the aim to find out the market share and market formed in each copra marketing institution in Parigi - Moutong Regency. The results of the research showed from the results of the analysis conducted is the market formed in copra farmers institutions are a perfect competition market, in the institution of traders collectors (middlemen) market formed is a monopoly market, just as the market formed in large traders is also monopoly. The cr4 value obtained is farmers by $30.82 \%$, collectors by $100 \%$, large traders by $100 \%$. From the results obtained the structure of the market is already affecting the market counduct copra, where the merchant become the determinant haraga copra is a collector to be the recipient of the price.in addition, traders do bond in terms of capital (dwon paymen). Copra market performance is inefficient, where copra farmers in Parigi - Moutong are more dominant in selling copra in three marketing lines that have many marketing agencies involved, with a margin of Rp 2,000. referring to the results, it is fair that the weak still of farmers reaching the market information, especially prices, as a result of the share received by farmers is low. Related to this, there needs to be strengthening in farmers institutions related to copra marketing system.
\end{abstract}

Keywords: structure, conduct, market performance, copra

http://dx.doi.org/10.21776/ub.agrise.2021.021.4.9

Received 30 July 2021

Accepted 10 October 2021

Available online 31 October 2021

\section{INTRODUCTION}

Indonesia as the largest country in Southeast Asia becomes one of the largest coconut production centers in the world with an average production of 18 million tons per year (Dirjenbun, 2020). Despite being the largest coconut production center in the world, Indonesia is only the second country after the Philippines as an exporter of coconut and processed. According to Maulana et al (2019) the difficulty of Indonesia becoming the largest coconut exporter in the world is due to the lack of post-harvest technology of coconut trees and the lack of optimal utilization of coconut plantations in order to increase the selling value and added value in coconut commodities and processed.

Indeed coconut has potential, it's just that various problems of Indonesian coconut is still not optimal from upstream to downstream. Indonesia coconut market potential has great opportunities plus the Indonesian coconut market that has touched the world market. High international market interest in copra used as cooking oil and other oils. (Puslitbang
2017). From the review should be an opportunity for the development of the people's economy, because 97\% of Indonesia's coconut plantations are dominated by people's plantations (Puslitbang 2017) so that the good bad coconut market in the market will have a direct impact on copra producers.

The gap in this marketing system illustrates the weak bargaining position of farmers in the marketing system so that producers are only price takers. Copra bargaining positions as well as price changes that occur in the market are strongly related to the condition of the structure and behavior of the copra market. This is because the structure and behavior of the market will affect the performance of the copra market and vice versa. The structure, behavior and performance approach of the market is an approach to know as a result of why marketing is inefficient. In the market structure (structure) copra will see the conditions of marketing agencies and copra producers involved in the market that will affect the process of copra price formation. While the behavior of the market (conduct) to identify the association of 
copra producers and copra marketing agencies in carrying out their business activities so as to affect the amount of marketing costs and margins. Cost, marketing margin and price, of the three indicators will be reflected in the market performance (performance) copra.

From various problems that occur in the marketing system that gives rise to certain behaviors akbibat of the market structure formed. According to Anindita and Baladina (2017) In particular, to know the causes and consequences of marketing systems why inefficient can use the SCP (Structure, Conduct, Performance) approach. The relationship of the three variables (SCP) has a linear relationship in which the market structure will affect market behavior then market behavior will affect performance (Martin 2002). The decision-making system of marketing agencies is influenced by the number of sellers and buyers, product differentiation, market entry barriers and market concentration. Thus, the formed market structure can influence market behavior, namely against sales and purchases by marketing agencies or intermediaries, determination and formation of prices and cooperation between marketing agencies themselves. Market performance is determined by the interaction between the structure and behavior of the market. The indicators used are marketing margin, farmer's share and marketing costs. Marketing efficiency can be analyzed through technical efficiency (operational) by measuring marketing costs, marketing margins and farmer's share.

Therefore, this study uses structure, conduct, and performance (SCP) analysis. From the analysis of SCP is expected to increase the profitability of farmers by finding more economical market channels so as to create an efficient marketing system, as well as provide relevant information related to the market chain. By identifying key market participants and their role in the market, identifying marketing paths, and identifying market structure, market behavior and market performance.

Based on the previous description, the problem of this research is the number of institutions involved and the length of marketing channels in Parigi Moutong regency so as to cause inefficient marketing, low copra prices and price fluctuations. Therefore, this research was conducted to answer the problem of copra market structure, market behavior formed and copra market performance in Parigi Moutong Regency. The purpose of the research results will describe the channel of copra marketing institutions, in parigi - Moutong district, copra market structure in Parigi - Moutong district, copra market counduct in Parigi Moutong district, copra market performance in Parigi - Moutong district.

\section{RESEARCH METHODS}

\section{Method of Determining The Location and Time of Research \\ This research was conducted in Bolano} Lambunnu Subdistrict, Parigi Regency - Moutong, Central Sulawesi Province. The determination of the location of the research was conducted by purposive method with the consideration that parigi - Moutong regency is the central district of coconut production in Central Sulawesi Province. Based on these considerations, then selected one sub-district that became the largest copra production center, namely Bolano - Lambunu Subdistrict. This research will be held in March - May 2021.

\section{Method of Determining Respondents}

The method of determining respondents is a method used in determining the people chosen to answer and provide information on the issue studied both in writing and verbally. Sugiyono (2001) stated that the population is a generalized area consisting of objects / subjects that have a certain quantity and characteristics set by researchers to be studied and then drawn conclusions. Based on this understanding, the population in this study is coconut farmers who process coconut into copra and also marketing institutions in Lambunu Village. Based on data from the Agriculture Office of Parigi - Moutong, the population of coconut farmers in Lambunu Village is 322 farmers.

Determination of samples, using simple random sampling method with Slovin formula. According to Sugiyono (2001). samples are a portion of the number and characteristics possessed by the population. By using slovin formula calculated research samples as follows:

information:

$$
\mathrm{n}=\frac{N}{1+N X(d . d)}
$$

$\mathrm{n} \quad$ : sample size

$\mathrm{N}$ : Population size

d : sampling error (10\%)

$\mathrm{n}=\frac{322}{1+322 \times(0,1 \times 0,1)}$

$\mathrm{n}=\frac{322}{4,22}$

$\mathrm{n}=76,30$

$\mathrm{n}=76$ farmer

From the calculation above, the sample taken in this study is as many as 76 coconut farmers with active farmer criteria in producing copra. While the determination of respondents sample for marketing institutions used a non probability sampling approach with snowball sampling method. Snowball sampling method is done by tracing information from copra producers until samples are obtained from respondents of copra marketing agencies. 


\section{Data Collection Methods}

The data used in this study are primary data and secondary data. The primary data in this study is data obtained by researchers directly from sources of information with interviews based on a list that has been created in a structured (questionnaire) in the form of structure, behavior, market performance ( access to market information, copra volume, barriers in and out of the market).

\section{Motode Data Analysis}

The data analysis methods used in this study are qualitative data and quantitative data. Qualitative analysis will be used to interpret the results of data processing using tabulations or images. Meanwhile, quantitative analysis used in this study is marketing margin, farmer share and profit-to-cost ratio analysis.

\section{Methods of Analysis of Market Structure, Market Conduct, Market Performance Analisis Struktur Pasar}

\section{Market Structure}

a) Market Share

Used to know the percentage of total sales, conducted at the level of farmers and marketing agencies and to know the structure of copra market in Parigi - Moutong district. Below is the formula used:

$$
\mathrm{MS}_{\mathrm{i}}=\frac{S 1}{\text { stot }} \times 100 \%
$$

where:

MSi : farmers market share (\%)

$\mathrm{S}_{\mathrm{i}}$ : farmers sales $(\mathrm{Rp})$

$\mathrm{S}_{\text {tot }}$ : total sales of the entire company (Rp)

b) Market Consentration

In analyzing market concentration, researchers used two analyses, namely Index Hirchman Herfindahl (IHH) and Consentratio Ratio for the Biggest Four $\left(\mathrm{CR}_{4}\right)$.

formula IHH : $\mathrm{IHH}=\left(\mathrm{Kr}_{1}\right)^{2}+\left(\mathrm{Kr}_{2}\right)^{2}+\ldots .+\left(\mathrm{Kr}_{\mathrm{n}}\right)^{2}$ IHH: Indeks Hirschman Herfindahl

$\mathrm{N}$ : Number of traders in a copra market area

$\mathrm{Kr}_{1}$ : Share of commodity buyers from traders to $\mathrm{I}(\mathrm{I}=1,2,3 . . \mathrm{n})$

formula CR4 :

CR4 $\frac{\text { the number of market share } 4 \text { buyer (traders) the most correct }}{\text { number of market share in all markets }} x 100$ c) Market Entry Barriers (Barrier to Entry)

In and out of the market analysts Use an approach Minimum Efficiency Scale (MES).

Formula MES :

$$
\text { MES } \frac{\text { PGreat Merchant sales }}{\text { Copra production at Kec Bolano Lambunu }}
$$

\section{Market Counduct}

In this study used to evaluate copra market behavior, namely: a). Pricing mechanism, in order to know how the formation of prices in copra marketing system. b). See whether there is collusion practices or other strategies among copra marketing agencies in determining prices, as well as finding out if there is a relationship that occurs between fellow marketing agencies or special treatment on goods on the market, in order to control the copra market.

\section{Market Performance}

Market performance is analyzed using prices as well as costs formed in the copra market. A single price and cost in marketing will affect the margin of marketing and farmer share as one of the indicators in oprasional efficiency.

a) Marketing Margin

According to Hudson (2007) margin marketing refers to price differences among institutions in the marketing system, in other words as the difference between what is paid by consumers and what is received by manufacturers.

Formula : $\mathrm{MP}=\mathrm{Pr}-\mathrm{PF}$ atau $\mathrm{MP}=\mathrm{B}+\mathrm{K}$

where:

$\mathrm{MP}=$ Marketing margin $(\mathrm{Rp} / \mathrm{kg})$

$\operatorname{Pr}=$ Prices at the consumer level $(\mathrm{Rp} / \mathrm{kg})$

$\mathrm{Pf}=$ Prices at the farmer level $(\mathrm{Rp} / \mathrm{kg})$

$\mathrm{B}=$ Copra marketing costs $(\mathrm{Rp})$

$\mathrm{K}=$ Copra marketing advantages ( $\mathrm{Rp})$

As for knowing the amount of Margin at each level of marketing institutions involved, it can be calculated by calculating the difference between the selling price and the purchase price at each level of the marketing agency.

Formula $: \mathrm{Mmi}=\mathrm{Pj}-\mathrm{Pb}$

Where:

Mmi : Margin marketing at the marketing agency level to-i

$\mathrm{Pj}: \quad$ : Selling price at marketing agencies to-i

$\mathrm{Pb}$ : : Purchase price at the level of the marketing agency to $-\mathrm{i}$

\section{b) Farmer Share}

Referring to Khols and Uhl (2002) crushing farmer share is a percentage of the price received by farmers with the price paid by consumer farmers in 
the form of percentage (\%). mathematically the farmer share formula as follows:

Formula $:$ SPF $=\frac{p f}{p r} \times 100 \%$

where:

$\mathrm{FS}=$ share price at the farmer level $(\%)$

$\mathrm{Pf}=$ prices at the farmer level (RP)

$\mathrm{Pr}=$ prices received by consumers $(\mathrm{Rp})$

c) Marketing Efficiency

Market Efficiency Index analysis is used to compare efficient levels between established marketing channels. The higher the ratio value, the higher.

$$
\text { Formula : } \mathrm{MEI}=\frac{F P}{M C+M M}
$$

As for knowing the amount of Margin at each level of marketing institutions involved, it can be calculated by calculating the difference between the selling price and the purchase price at each level of the marketing agency. Thus, the way of calculating marketing margin at each marketing institution is as follows:

Formula : $\mathrm{Mmi}=\mathrm{Pj}-\mathrm{Pb}$

where:

Mmi = Marketing margin at the i.e. marketing agency level

$\mathrm{Pj}=$ Selling price at the level of the $\mathrm{i}-\mathrm{i}$ marketing agency

$\mathrm{Pb}=$ Purchase price at the level of the $\mathrm{i}-\mathrm{i}$ marketing agency

\section{RESULT AND DISCUSSION \\ Marker Structure}

From the results of the calculations carried out refers to the market share at the farmer level that varies, the value of market share obtained is quite high at $15.94 \%$, based on the cr4 calculation of the results obtained is $30.82 \%$, it indicates that the market formed is a perfect competition market, while the result of the value of ihh obtained, shows 436,192 which indicates that the market is low consenytasinya level or farmers' bargaining position is very low with criteria ihh $>1000$.

While at the level of copra collectors from the results obtained is $50 \%$. Based on the results of the calculation cr4 the result is $100 \%$ which means that the market formed is a monopoly market, with a fairly high bargaining position with criteria ihh 1,800 $-10,000$.

Furthermore, the share formed at the level of large merchant marketing institutions from the results of cr4 calculation is $100 \%$ which describes the market formed at the level of large merchant marketing institutions namely monopoly, with a value of ihh of 3750 , based on the criteria that range $1,800-10,000$ indicates high concentration.
The result of barriers in and out of the market, obtained from the calculation using the Minimum Efficiency Scale (MES) approach of $18.27 \%$, from the results illustrates that the market in and out of the copra market in Parigi - Moutong is indicated by high market barriers. Based on wilson opinion (1967) in the journal Alistair (2004) revealed the value of MES if the amount is more than $10 \%$ then the barriers to entering the market is high. From the observations in the field shows one of the obstacles of new entrants entering the market, namely related to capital and farmers' ties to old traders (client) that form a dwon paymen system.

\section{Market Condunct}

Market behavior refers to the actions and behaviors of institutions in a particular structure. This section refers to marketing functions, haraga determination practices, payment systems and marketing channels. Based on the results of the analysis of market behavior in each copra marketer in Parigi - Moutong Regency as follows.

1. Marketing Function

a) Marketing Functions at the Farmer Level

At the farmer level has more marketing functions including exchange function as seller, physical functions such as, stripping, separation of coconut meat, drying process, packaging process (disak), storage. While the function of the facility is, risk management shrinkage. More details below in table 1 .

Table 1 Marketing Functions Performed At the Copra Farmer Level

\begin{tabular}{lll}
\hline Marketing Institute & Marketing Functions & information \\
\hline Copra Farmers & Exchange Function & Sales \\
\hline & Physical Function & Stripping Process \\
& & Separation of meat \\
& & Drying \\
& & Packaging (disak) \\
& & Storage \\
\hline & Facility Functions & Risk Management
\end{tabular}

Source : primary data processed 2021

b) Marketing Function at the Level of Collectors ( middlemen)

While the physical function in the collecting institution is less in the appeal of farmers, for more details here in table 2 .

Table 2. Marketing Functions Performed at the Collector's Level

\begin{tabular}{lll}
\hline Marketing Institute & Marketing Functions & Information \\
\hline Collector Merchant & Exchange Function & $\begin{array}{l}\text { purchase } \\
\text { Sales }\end{array}$ \\
\hline & Physical Function & Storage \\
& & Transportation \\
\hline & Facility Functions & Risk financing \\
& & information \\
\hline
\end{tabular}

Source : primary data processed 2021 
Based on table 2. That the marketing function performed by the collector merchant is, in the marketing function as a buyer and seller, on the physical function of conducting the establishment, transportation, on the function of costing risk facilities and information.

c) Physical Functions at the Large Trader Level In the marketing function performed by large traders, among others as follows in table 3 below.

Table 3. Functions of marketing functions in Large traders.

\begin{tabular}{lll}
\hline Marketing Institute & Marketing Functions & information \\
\hline Collector Merchant & Exchange Function & purchase \\
& Sales \\
\hline & Physical Function & storage \\
& Transportation \\
\hline \multirow{2}{*}{ Fungsi Fasilitas } & $\begin{array}{l}\text { Risk financing } \\
\text { information }\end{array}$ \\
\hline
\end{tabular}

Source : primary data processed 2021

Refer to table 3, seen in the marketing function that exists in large traders, namely, the marketing function as a buyer and seller, on the physical function of only carrying out storage and transportation, on the function of facilities to perform the risk of financing and information, just as collectors do.

\section{d) Pricing Practices}

Referring to the pricing mechanism, it also has a relationship with the structure of the market formed. For more details here is the mechanism of copra pricing in each marketing agency.

Table 4 Copra Pricing At Every Level of Marketing Institutions

\begin{tabular}{|c|c|c|c|}
\hline $\begin{array}{l}\text { Marketing } \\
\text { Institute } \\
\text { Marketing }\end{array}$ & Pricing Resources & Pricing Process & $\begin{array}{c}\text { Percentage } \\
(\%)\end{array}$ \\
\hline \multirow{2}{*}{ farmer } & \multirow{2}{*}{$\begin{array}{l}\text { Collector traders, } \\
\text { fellow farmers }\end{array}$} & Determined by the & 87 \\
\hline & & Bargaining & 13 \\
\hline \multicolumn{3}{|l|}{ Total } & 100 \\
\hline \multirow{2}{*}{ Collector Merchant } & \multirow{2}{*}{$\begin{array}{l}\text { Big traders, other } \\
\text { collectors }\end{array}$} & $\begin{array}{l}\text { Determined large } \\
\text { traders }\end{array}$ & 100 \\
\hline & & Bargaining & \\
\hline \multicolumn{3}{|l|}{ Total } & 100 \\
\hline Great Traders & \multirow{2}{*}{$\begin{array}{l}\text { Factory, fellow big } \\
\text { trader }\end{array}$} & factory & 100 \\
\hline - & & Bargaining & 100 \\
\hline
\end{tabular}

Source : primary data processed 2021

Based on table 4, that pricing Determination at the farmer level is more done by collectors seen from the percentage yield of $87 \%$ or 66 copra farmers, for farmers who bargain on collectors $13 \%$ or 10 patani copra. Pricing at the collecting merchant institution is determined by the large trader by a percentage of $100 \%$, while the one doing the bargain does not exist. At the level of large traders related to pricing, it is determined by copra processing plants. The percentage value is $100 \%$.

Related to the price in large traders, the price received by large traders from copra factories will be the benchmark to be informed to the collector pedegang in determining the price. Then the information received by collectors from large traders will be the benchmark also to farmers (copra producers). Therefore, it can be concluded that the position of copra farmers against collectors is only a price taker or price recipient.

e) Payment System

Referring to this payment system includes activities performed between the seller and the buyer, for more details here in table 5 .

Table 5. Payment System

\begin{tabular}{|lllr|}
\hline Seller & Buyer & Payment system & Percentage (\%) \\
\hline farmer & factory & Cash and Discounts & \\
\hline & & $\begin{array}{l}\text { Some are paid in advance, the rest } \\
\text { after selling }\end{array}$ \\
\hline & paid after practice \\
\hline & cash \\
\hline farmer & Collector Merchant & Cash and Discounts \\
\hline & $\begin{array}{l}\text { Some are paid in advance, the rest } \\
\text { after selling }\end{array}$ \\
\hline & paid after practice \\
\hline & cash \\
\hline farmer & Great Traders & Cash and Discounts \\
\hline & $\begin{array}{l}\text { Some are paid in advance, the rest } \\
\text { after selling }\end{array}$ \\
\hline & paid after practice \\
\hline cash \\
\hline steamer & great traders & Cash and Discounts \\
\hline & & $\begin{array}{l}\text { Some are paid in advance, the rest } \\
\text { after selling }\end{array}$ \\
\hline
\end{tabular}

Source : primary data processed 2021

Based on table 5, refers to farmers who sell to the factory the payment system is paid after practice. While in the payment system that occurs to farmers who make cash payment system and deductions by collectors is $87 \%$ percentage of farmers, which is meant here is farmers who take panjar to collectors before harvesting, so that when farmers sell then made cuts, therefore farmers only receive a portion of the copra price that he sells.

The remaining $13 \%$ of the prepaid payment system is paid after the sale, it is because the amount of copra production they sell to the collector is quite large, which means it needs a large enough capital to pay all, therefore, the collectors do the way partly paid in advance, the rest after selling based on the agreement of farmers and collectors. The same thing also happens to farmers who sell a large amount of the pay system Partly paid in advance, the rest after selling.

f) Marketing Channels.

From the results that can be that the marketing channel in Kabupten Parigi - Moutong that has three marketing channels, for more details here is the picture in figure 10 below. 


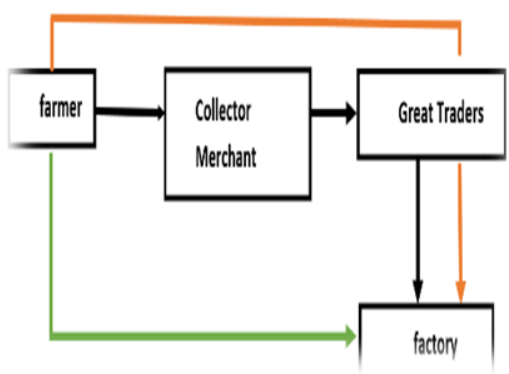

Figure 1. Copra Marketing Channel

Based on figure 1, it can be concluded that efficient marketing becomes a reference for farmers as a reference to get a higher profit that is on line one, where the line one farmers directly sell their crops to the factory without hasur passing through other marketing agencies, as done on lines two and three.

\section{Market Performance}

Referring to the analysis of market performance, in this study will look at how much margin on each marketing channel, to see the margin in each marketing institution will be divided into existing marketing agencies. The aspects used in analyzing market performance are marketing margin, farmer share, marketing efficiency.

\section{a) Magin Marketing}

Marketing margin is the difference between the price paid by the trader and the price received by the farmer. Margins can be calculated for each stage in the marketing chain, for example, the spread of prices from farmers, collectors, large traders to pabirik. More details are below in table 5 :

Table 5 Margin Marketing

\begin{tabular}{|c|c|c|c|c|}
\hline \multirow{2}{*}{$\mathrm{N}$} & \multirow[b]{2}{*}{ Description } & \multicolumn{3}{|c|}{ Marketing Channels } \\
\hline & & l(Rp/Kg/Season) & 2 (Rp/Kg/Season) & 3 (Rp/Kg/Season) \\
\hline \multirow{5}{*}{ l } & farmer & & & \\
\hline & Production costs & $3.014,50$ & $3.014,50$ & $3.014,50$ \\
\hline & marketing costs & 100,00 & & \\
\hline & selling price & $12.000,00$ & $11.200,00$ & $10,000,00$ \\
\hline & keuntungan & $8.885,50$ & $8.185,50$ & $6.985,50$ \\
\hline \multirow{6}{*}{2} & Collector merchants & & & \\
\hline & purchase price & & & $10.000,00$ \\
\hline & marketing costs & & & 116,67 \\
\hline & \begin{tabular}{|l|} 
selling price \\
\end{tabular} & & & $11.233,00$ \\
\hline & advantage & & & $1.116,33$ \\
\hline & steamer margin & & & $1.233,00$ \\
\hline \multirow{6}{*}{3} & Great traders & & & \\
\hline & purchase price & & $11.200,00$ & $11.233,00$ \\
\hline & marketing costs & & 338,35 & 199,55 \\
\hline & selling price & & $12.000,00$ & $12.000,00$ \\
\hline & advantage & & 461,65 & 567,45 \\
\hline & marketing margin & & 800,00 & 767,00 \\
\hline \multicolumn{2}{|c|}{ Total Profit } & 8.888 .50 & $8.647,15$ & $8.669,28$ \\
\hline \multicolumn{2}{|c|}{ Total Margin } & 100,00 & 800,00 & 2000,00 \\
\hline
\end{tabular}

Source : primary data processed 2021
Based on table 5, that the highest marketing margin from the calculation results is on channel three of $\operatorname{Rp} 2000.00$ while the lowest is on channel one as much as Rp 100.00. So it can be concluded that the lowest and most efficient marketing margin is on channel one, therefore the next reference for farmers to make sales should follow channel one with a low margin.

\section{b) Farmer Share}

Farmer share is a percentage of the price received by farmers with the price paid by consumers. Some things that affect farmer share, including processing rate, transportation cost, number of products. Here is the farmer share table in each marketing channel in table 6.

Table 6. Farmers Share On Copra Marketing Channels

\begin{tabular}{|c|c|c|c|c|c|c|}
\hline \multirow[b]{2}{*}{ Jarket Participants } & \multicolumn{6}{|c|}{ Marketing Channek } \\
\hline & $\begin{array}{c}1 \\
(\mathrm{Rp} \mathrm{Kg})\end{array}$ & (9) & $\begin{array}{c}2 \\
\left(\mathrm{Rp}_{p} \mathrm{~K}_{\mathrm{g}}\right)\end{array}$ & (\%) & $\begin{array}{c}3 \\
\left(R_{p} \mathrm{Kg}\right)\end{array}$ & (9i) \\
\hline furner & 12000,00 & \multirow{3}{*}{100} & 11200,00 & \multirow{3}{*}{93} & $\begin{array}{r}10,000,0 \\
0\end{array}$ & \multirow{3}{*}{83} \\
\hline Collector merchants & & & & & $\begin{array}{r}11233,0 \\
0\end{array}$ & \\
\hline Great traders & & & 12000,00 & & $\begin{array}{r}12000,0 \\
0\end{array}$ & \\
\hline
\end{tabular}

Source data primer diolah 2021.

Based on table 6, it can be concluded that the top share price received by farmers is in the marketing channel one (1) high price share due to a short marketing channel. Where farmers directly sell their crops to copra processing plants. Therefore, the share price of copra in the market is only controlled by copra farmers. Trade on the marketing channel three (3) shares received by farmers is quite small because of the length of marketing channels to get to the factory. therefore it is recommended to farmers to sell their crops to channel one, where the share price received by farmers is higher.

c) Marketing Efficiency

In this analysis, discuss related to the comparison of the net price received by farmers to the total marketing cost plus the total margin. For more details see the results of the calculation, here in table 7.

Table 7. Comparison of Marketing Efficiency Index of Each Marketing Channel.

\begin{tabular}{|c|c|}
\hline Marketing Channels & Marketing Efficiency Index \\
\hline 1 & 3,85 \\
\hline 2 & 2,70 \\
\hline 3 & 2,44 \\
\hline
\end{tabular}

Source : primary data processed 2021 
Based on table 7, the lowest niliai is seen in the marketing path 3 . Marketing channel 3 is the longest marketing channel with the involvement of 2 marketing agencies namely collectors and large traders in the copra market. Based on the description, it can be concluded that marketing channel 1 is a more efficient marketing channel than other marketing channels. In marketing channel 1 do marketing to the maximum so that it can feel enough profit in comparison to other marketing channels, in addition to the marketing channel 1 is the shortest marketing channel so that the distribution flow to consumers (factories) is not much involvement of marketing agencies in it.

\section{CONCLUSION}

The structure of the kopara market in Parigi - Moutong regency tends to be imperfect competition or Monopolistic. The market is quite concentrated among collectors and large traders, so the competition is badly affected. This is also evidenced by the small number of traders (buyers), rather than farmers (sellers) who are many. Therefore, it can be concluded that the market structure at the farmer level tends to form a perfect competition market. While the market formed in the institution of collector traders and large merchant institutions is a monopoly.

Counduct copra market in Parigi - Moutong district shows there are dominant marketing institutions in copra marketing activities. the institution called the collecting agency. In marketing activities there is a marketing function, capital ties conducted by farmers and traders collectors, it causes farmers to be weak in pricing, based on the calculation that $87 \%$ of collectors master the determination of prices from farmers. While farmers who do bargaining only $3 \%$. In addition, there is also collusion in the cash payment system and cutting the price of farmers' crops.

Copra market performance in Parigi Moutong regency has three marketing channels. Adapu highest margin is on the marketing line three with a margin of 2000.00. The number of institutions involved that resulted in three marketing channels made the margin to be the highest, as a result of the high margin caused the farmer share to be low. The marketing channel that becomes the best recommendation or can be said to be efficient is on the marketing channel 1 , where one marketing channel directly sells its crops to the end consumer (factory).

\section{SUGGESTION}

1. The government may participate or intervene in the problem of plantation commodities in the issue of prices, especially in coconut commodities (copra).
2. Establishing agricultural co-ordration institutions, or partnerships with villages such as the establishment of BUMDES in the scope of plantation commodities, so that it will be used as a capital lender, transportation procurement, also as a suggestion of sources of information for farmers in accessing copra marketing.

3. Strengthening institutions in copra marketing, especially in farmers' institutions, so that later the profits received by farmers will be greater.

\section{REFERENCES}

Abubakar, I. (2016). Analisis Structure, Conduct dan Performance pada Pasar Kakao: kasus di Kabupaten Parigi Moutong Provinsi Sulawesi Tengah.

Amalia Nurul Dwi. (2013). Sistem Pemasaran Karet Rakyat Dengan Pendekatan Struktur, Perilaku, Dan Kinerja Pasar. 4(3), 237-244. di Provinsi Jambi

https://doi.org/10.21082/jtidp.v4n3.2013.p237 $-244$

Anggraeni, M. D., \& Baladina, N. (2017). Analisis Struktur, Perilaku dan Penampilan Pasar Kentang di Desa Sumberbrantas, Kecamatan Bumiaji, Kota Batu. Jurnal Ekonomi Pertanian Dan Agribisnis, 1(2), 69-79. https://doi.org/10.21776/ub.jepa.2017.001.02. 1

Apriyanti, I., \& Ramadhani, J. (2018). Strategi Pemasaran Kelapa Sawit Melalui Pendekatan Analisis Structure, counduct, Performance ( $S C P$ ) di Kabupaten Simalunggung.

Ardiyanto Beni. (2015). Struktur, Perilaku dan Kinerja Pasar Ubi Jalar (Ipomoea batatas L.) (Studi Kasus di Desa Penanggungan, Kecamatan Trawas, Kabupaten Mojokerto).

Bain, J. (1968). Industrial Organization 2nd edition, John Wiley and Sons Inc., New York.

Dana, P., \& Haji, T. (2018). Analisis pangsa pasar dalam mengembangkan produktivitas dana talangan haji (studi kasus: kspps mitra usaha ideal bungah gresik) skripsi.

Dirjenbun. (2020). Statistik Perkebunan Indonesia Komoditas Kelapa Tahun 2018-2020 (pp. 1118).

http://ditjenbun.pertanian.go.id/?publikasi=bu ku-publikasi-statistik-2018-2020

Gangkur, F. (2020). Analsis Struktur, Perilaku dan Kinerja Pasar Tomat. di Manggarai Nusa Tenggara Timur

Hutabarat, B., Pranadji, T., \& Nasution, A. (2016). Dimensi perdagangan kelapa dan kopra rakyat di Sulawesi Utara. Forum Penelitian Agro Ekonomi, $11(2), \quad 24$. https://doi.org/10.21082/fae.v11n2.1993.24-36

Khamidi, S. (2008). Shofwan Khamidi Achmad Fauzi DH Imam Suyadi Fakultas Ilmu Administrasi 
Universitas Brawijaya Malang. 3.

Lee, C., \& Lee, C. (2007). SCP , NEIO and Beyond. 2007.

Maiti, \& Bidinger. (1981). 済無No Title No Title. In Journal of Chemical Information and Modeling (Vol. 53, Issue 9).

Maulana, R., Tinggi, S., Migas, T., \& Design, M. (2019). Comparative Study Perkebunan Kelapa ( Coconut ) di Indonesia dan Otomatisasi Pengeringan ( Oven Drier ) pada Industri Briket Tempurung Kelapa. November 2018.

https://doi.org/10.13140/RG.2.2.14736.05127

Nasution, A., \& Rachmat, M. (2016). Agribisnis Kelapa Rakyat di Indonesia: Kendala dan Prospek. Forum Penelitian Agro Ekonomi, 10(2-1), https://doi.org/10.21082/fae.v10n2-1.1993.1928

Nurdiyah. (2014). Analisis struktur, perilaku, dan kinerja pemasaran jambu mete gelondongan di kabupaten muna provinsi sulawesi tenggara nurdiyah.
Purcell,D. (1973).An Approach to Research on Vertical Integration: The Beef System in Oklahoma, American Journal of Agriculture Vol. 55, No. 1.

Pohan, I. P. (2011). Analisis nilai tambah dan pemasaran kopra. Program Studi Agribisnis FP $U S U$.

Regowo, N. H. (2008). Analisis integrasi pasar kopra dunia dengan pasar kopra dan minyak goreng kelapa domestik.

Rusno, A. L. (2014). Hubungan harga kopra terhadap tingkat produksi kopra di kabupaten minahasa selatan.

Supranoto, M. (2009). Sertifikasi. In Strategi Menciptakan Keunggulan Bersaing Produk Melalui Orientasi Pasar, Inovasi, dan Orientasi Kewirausahaan dalam Rangka Meningkatkan Kinerja Pemasaran.

Yandra, A. (2017). Fluktuasi Harga Kelapa Terhadap Pendapatan. 14(2), 204-217.

Waldman, DE dan Jensen, EJ. 2007. Industrial Organization. Theory and Practice. Third Edition. United States of America (US): Pearson Education. 